\title{
Five-years review of obstetric hysterectomy at tertiary care center
}

\author{
Anita G. Pawar*, Mangala A. Shinde, Sarasjothi M., Priyanka B. Nemagouda
}

Department of Obstetrics and Gynecology, VDGIMS, Latur, Maharashtra, India

Received: 06 November 2020

Revised: 12 December 2020

Accepted: 14 December 2020

\section{*Correspondence:}

Dr. Anita G. Pawar,

E-mail: dranita1983@gmail.com

Copyright: ( ) the author(s), publisher and licensee Medip Academy. This is an open-access article distributed under the terms of the Creative Commons Attribution Non-Commercial License, which permits unrestricted non-commercial use, distribution, and reproduction in any medium, provided the original work is properly cited.

\section{ABSTRACT}

Background: Obstetric hysterectomy $(\mathrm{OH})$ is indicated as last resort operation to save the life of the mother and associated with high complication rates, so requires a highly experienced and skilled medical team ,to solve any complication. Objective was to identify incidence, demographic profile, indications, risk factors, complications, maternal morbidity and mortality associated with obstetric hysterectomy.

Methods: Retrospective analytical study of 47 case records is done over period of last 5 years from October $1^{\text {st }}$ October 2015 to $30^{\text {th }}$ September 2020 at VDGIMS, a tertiary care center, Latur. Results are expressed in frequency and percentages.

Results: In our study, the rate of $\mathrm{OH}$ was 1.1/1000 deliveries. Most common (68\%) age group was 21-30 yrs, majority (70\%) were multipara, and booked (76\%). Most common indication of $\mathrm{OH}$ was atonic PPH (65\%), followed by traumatic $\mathrm{PP}$, including rupture uterus $(21 \%)$, and placenta acreta $(10 \%)$. Most $\mathrm{OH}$ was performed on emergency basis $(91 \%)$ and of subtotal type $(95 \%)$. Major mode of delivery was cesarean $65 \%$ and vaginal delivery in $21 \%$ cases. Most common risk factors were placental causes (55\%), previous LSCS (48\%) and hypertensive disorder $(31 \%)$. High maternal morbidity in form of $100 \%$ blood transfusion rate, $93 \%$ ICU admission, inotropes and ventilator support in $59 \%$ cases and prolonged hospital stay in $75 \%$ cases seen. Most common complication were hemorrhagic shock $21 \%$, DIC (29\%), renal failure (12\%) and septic shock (14\%) with maternal death rate of $23 \%$ was noted.

Conclusions: Obstetric hysterectomy is a necessary life-saving operation, but also associated with high maternal morbidity and mortality, which can be minimized with timely done procedure by experienced person.

Keywords: Atonic PPH, Abnormal placentation, Complications, Obstetric hysterectomy, Risk factors

\section{INTRODUCTION}

Hysterectomy performed in an obstetric case is called Obstetric hysterectomy $(\mathrm{OH})$. It is the removal of uterus at the time of caesarean section, following caesarean section, or immediately after vaginal delivery within 24 hrs or in the period of puerperium in order to save maternal life. ${ }^{1}$ The $1^{\text {st }}$ successful obstetric hysterectomy was performed by Eduardo Porro in 1876 in case of postpartum haemorrhage. ${ }^{2}$ In developing countries most common indications are post-partum hemorrhage and ruptured uterus when conservative measures fail to control bleeding. ${ }^{3}$ In recent times, incidence of $\mathrm{OH}$ is rising worldwide mostly due to increased cesarean section rate because its increasing the number of scar rupture, abnormal placentation i.e. placenta praevia and morbidly adherent placenta, and overall increasing the incidence of $\mathrm{OH}$ in both developed and in developing countries. $^{1,4}$ An uncommon indication for cesarean 
hysterectomy are puerperal uterine infection,large leiomyoma and cervical cancer. ${ }^{1}$

$\mathrm{OH}$ is referred as peripartum hysterectomy when performed after 24 weeks of gestation. Peripartum hysterectomy is broader term and combines both cesarean hysterectomy (when it is done at the time of cesarean delivery) and postpartum hysterectomy (when it is done either after vaginal delivery or cesarean delivery, skin closure after cesarean section). ${ }^{1}$

$\mathrm{OH}$ is associated with high risk of intra operative and post-operative complications because of largely unplanned nature of surgery which is often done on an emergency basis for intractable obstetric hemorrhage, except in cases of cesarean hysterectomy which could be done electively to some extent, as those in antenatally prediagnosed cases of morbidly adherent placenta. ${ }^{1}$ Major intraoperative complications are increased blood loss and risk of urogenital tract injury. ${ }^{5}$ Cesarean hysterectomy complication rate is importantly affected by whether operation is performed electively or emergently. Planned cases have lower rates of blood loss, less need of blood transfusion and fewer urinary tract injuries compared to emergency procedure. ${ }^{1}$

Obstetric hysterectomy can save many maternal lives. Fast decision and excellent surgical skills is required to save life while doing obstetric hysterectomy. Early resuscitation, on time availability of blood and blood components helps to improve hemodynamic status of patient which in turn, helps the patient to withstand the surgical procedure and anaesthesia. The decision of obstetric hysterectomy particularly in the younger age group and low parity causes a great dilemma to the surgeon. Timely decision prevents catastrophes.

\section{METHODS}

Retrospective analytical study of case records over period of last 5 years from $1^{\text {st }}$ October 2015 to $30^{\text {th }}$ September 2020 at Vilasrao Deshmukh Government Institute of Medical Science, Tertiary Care Center. 47 patient' files with obstetric hysterectomy were revived and data obtained were recorded in a structured proforma. Maternal demographic characteristics, indications, type of hysterectomy, risk factors, maternal and fetal outcome and complications that occurred were looked into. Data were collected in MS excel sheet and results were expressed in frequency, percentages.

\section{Inclusion criteria}

All the cases of $\mathrm{OH}$ done at VDGIMS, Latur, irrespective of gestational age (including all trimesters) and indications.

\section{Exclusion criteria}

Women who were admitted following an $\mathrm{OH}$ done from elsewhere, were not included in the study.

\section{RESULTS}

There were total 41248 deliveries during the study period of 5 years. There were 47 cases of Obstetric hysterectomy $(\mathrm{OH})$ during this period. The rate of $\mathrm{OH}$ was $1.1 / 1000$ deliveries.

Table 1: Demographic characteristics of women. $(\mathrm{N}=47)$.

\begin{tabular}{|c|c|c|}
\hline Characteristics & Frequency (N) & $\%$ \\
\hline \multicolumn{3}{|l|}{ Age } \\
\hline$<20$ years & 6 & 12.7 \\
\hline $21-30$ years & 32 & 68 \\
\hline $31-35$ years & 6 & 12.7 \\
\hline$>35$ years & 3 & 6.3 \\
\hline \multicolumn{3}{|l|}{ Residence } \\
\hline Rural & 25 & 53.1 \\
\hline Urban & 22 & 46.8 \\
\hline \multicolumn{3}{|l|}{ Booking status } \\
\hline Booked & 36 & $76.5 \%$ \\
\hline Booked in & 4 & 8.5 \\
\hline Booked out (referred) & 32 & 68 \\
\hline Unbooked & 11 & 23.4 \\
\hline \multicolumn{3}{|l|}{ Parity } \\
\hline Primipara & 14 & 29.7 \\
\hline Multipara & 26 & 55.3 \\
\hline Grandmultipara & 7 & 14.8 \\
\hline Total multipara $(b+c)$ & 33 & 70.2 \\
\hline \multicolumn{3}{|l|}{ Gestational age } \\
\hline$<24$ wks & 6 & 12.7 \\
\hline $1^{\text {st }}$ trimester & 1 & 2.1 \\
\hline $2^{\text {nd }}$ trimester & 5 & 10.6 \\
\hline$>24$ weeks & 41 & 87.2 \\
\hline 24-36.6 weeks (preterm) & 19 & 40.4 \\
\hline$>37$ weeks (term) & 22 & 46.8 \\
\hline \multicolumn{3}{|l|}{ Scar status } \\
\hline Previous lscs (scarred) & 23 & 48.93 \\
\hline$<24$ weeks & 4 & 8.5 \\
\hline$>24$ weeks & 19 & 40.4 \\
\hline Unscarred & 24 & 51.06 \\
\hline$<24$ weeks & 2 & 4.2 \\
\hline$>24$ weeks & 22 & 46.8 \\
\hline \multicolumn{3}{|l|}{ Mode of delivery } \\
\hline \multicolumn{3}{|l|}{$<24$ weeks } \\
\hline $1^{\text {st }}$ trimester-MVA & 1 & 2.1 \\
\hline \multicolumn{3}{|l|}{$2^{\text {nd }}$ trimester } \\
\hline Spontaneous abortion & 4 & 8.5 \\
\hline Hysterotomy & 1 & 2.1 \\
\hline \multicolumn{3}{|l|}{$>24$ weeks } \\
\hline Previous lscs(scarred) & 19 & \\
\hline Repeat LSCS & 17 & 89.5 \\
\hline VBAC & 2 & 10.5 \\
\hline Unscarred & 22 & \\
\hline LSCS & 14 & 63 \\
\hline Vaginal delivery & 8 & 36.3 \\
\hline Total LSCS $(17+14)$ & 31 & 65 \\
\hline Total vaginal delivery $(8+2)$ & 10 & 21 \\
\hline
\end{tabular}


Table 1 shows demographic characteristics of $\mathrm{OH}$ cases. Most common, 68\% age group is 21-30 years, teenager group ( $<20$ years) also includes 6 cases, $(12.7 \%)$, and elderly ( $>35$ years) noted in 3 cases $(6.3 \%)$. Residence wise distribution showed $53 \%$ cases and $46 \%$ cases were from rural and urban areas respectively. Booking status showed most $(76 \%)$ cases were booked, out of which $68 \%$ were booked out (referred) cases and only $23 \%$ cases were unbooked. Parity wise distribution of cases includes $29 \%$ primipara, multipara $55 \%$ (26 cases) and 7 cases (14\%) of grandmultipara. Out of 47 cases of $\mathrm{OH}, 6$ cases $(12.7 \%)$ were $<24$ weeks of gestational age which includes one case $(2.1 \%)$ of $1^{\text {st }}$ trimester and 5 cases $(10 \%)$ of $2^{\text {nd }}$ trimester. Most cases $(87 \%)$ are of $>24$ weeks of gestation, out of which term cases (46\%) are more common than preterm $(40 \%)$ cases. Mode of delivery pattern showed most cases $(65 \%)$ were delivered by cesarean section, while vaginal delivery cases were $21 \%$ only.

In $2^{\text {nd }}$ trimester cases mode of delivery was spontaneous abortion in $4(8.5 \%)$ cases and hysterotomy in 1 case $(2.1 \%)$. One case of $1^{\text {st }}$ trimester was case incomplete abortion done by MVA. Onset of labour in most cases (76\%) was spontaneous and induced in only $19 \%$ cases.

Table 2 shows type pattern of $\mathrm{OH}$ cases. According to situation, most cases (91\%) were done on emergency basis while planned $\mathrm{OH}$ happened in only (8.5\%) cases, those were the cases of placenta accreta diagnosed antenatally. According to timing, most cases (57\%) are of cesarean $\mathrm{OH}$ and only $10(21 \%)$ cases were of postpartum $\mathrm{OH}$ followed after vaginal delivery, 4 cases $(8 \%)$ after cesarean section. There were 6 cases $(12 \%)$ of postabortal $\mathrm{OH}$, out of which $4(8 \%)$ cases were done after spontaneous abortion due to PPH, 1 case of after hysterotomy and 1 case of $1^{\text {st }}$ trimester $\mathrm{OH}$ followed after MVA.

Table 2: Type of $\mathrm{OH}(\mathrm{N}=47)$.

\begin{tabular}{|lll|}
\hline Type & Frequency(N) & Percentage \\
\hline According to situation & & \\
\hline Planned & 4 & 8.5 \\
\hline Emergency & 43 & 91.4 \\
\hline According to timing & & \\
\hline Postpartum & 14 & 29.7 \\
\hline After vaginal delivery & 10 & 21.2 \\
\hline Post cesarean & 4 & 8.5 \\
\hline Cesarean & 27 & 57.4 \\
\hline Postabortal & 6 & 12.7 \\
\hline $\begin{array}{l}\text { After spontaneous } \\
\text { abortion }\end{array}$ & 4 & 8.5 \\
\hline With hysterotomy & 1 & 2.1 \\
\hline After MVA & 1 & 2.1 \\
\hline According to type of surgery & \\
\hline Subtotal OH & 45 & 95 \\
\hline Total OH & 2 & 4.2 \\
\hline
\end{tabular}

Table 3: Indication of $\mathrm{OH}(\mathrm{n}=47)$.

\begin{tabular}{|c|c|c|c|c|c|c|c|}
\hline \multirow{3}{*}{ Indication } & \multicolumn{2}{|c|}{$<24$ wks $\quad(n=6)$} & \multicolumn{2}{|c|}{$>24$ wks $(n=41)$} & & \multirow{3}{*}{$\begin{array}{l}\text { Total } \\
(\mathrm{n}=47)\end{array}$} & \multirow{3}{*}{$\%$} \\
\hline & \multirow{2}{*}{$\begin{array}{l}1^{\text {st }} \\
\text { trimester }\end{array}$} & \multirow{2}{*}{$\begin{array}{l}2^{\text {nd }} \\
\text { trimester }\end{array}$} & \multirow{2}{*}{ Cesarean } & \multicolumn{2}{|l|}{ Postpartum } & & \\
\hline & & & & $\begin{array}{l}\text { After vaginal } \\
\text { delivery }\end{array}$ & $\begin{array}{l}\text { Post } \\
\text { cesarean }\end{array}$ & & \\
\hline Atonic PPH & 0 & 1 & 19 & 7 & 4 & 31 & 65.9 \\
\hline $\begin{array}{l}\text { Trumatic PPH (rupture } \\
\text { uterus/ uterine wall } \\
\text { hematoma) }\end{array}$ & 1 & 3 & 4 & 2 & & 10 & 21.2 \\
\hline $\begin{array}{l}\text { Morbidaly adherent } \\
\text { placenta }\end{array}$ & 0 & 1 & 4 & & 0 & 5 & 10.6 \\
\hline Puerperal sepsis & 0 & 0 & 0 & 1 & & 1 & 2.1 \\
\hline Other causes & 0 & 0 & 0 & & 0 & 0 & 0 \\
\hline Total & 1 & 5 & 27 & 10 & 4 & 47 & $100 \%$ \\
\hline
\end{tabular}

Table 3 shows indication of $\mathrm{OH}$ cases. In our study, most common indication is atonic PPH (65\%), followed by traumatic $\mathrm{PPH}(21 \%)$, morbidly adherent placent contributed to $5 \%$ each and only 1 case $(2.1 \%)$ attributed to puerperal sepsis.

Table 4 shows risk factors associated $\mathrm{OH}$. In our study most common(48\%) risk factor found was placental causes $55 \%$ (abruption $25 \%$, placenta previa $19 \%$, placenta acreta $10 \%)$ followed by previous Lscs $(48 \%)$, hypertensive disorder $(31 \%)$, and obstructed labour in
$10 \%$ and twin pregnancy in $8.5 \%$ cases. There was history of (h/o) injury due to instrumentation in 2 cases (i.e. in $1^{\text {st }}$ trimester case and one of the cases of $2^{\text {nd }}$ trimester) and h/o instrumental delivery in one case $(2.1 \%)$ of IUD.

Table 5 shows analysis of clinical profile of $\mathrm{OH}$ cases. Preoperative $\mathrm{Hb}$ value was $<7 \mathrm{gm} \%$ in $46 \%$ cases suggestive of severe blood loss and $>7 \mathrm{gm} \%$ in $53 \%$ cases. On admission, $27 \%$ were clinically in shock status while $72 \%$ patients were clinically not in shock. Blood 
transfusion requirement was $100 \%$ and $>4$ units transfusion (massive transfusion) was required in $53 \%$ cases. ICU admission was required in almost $93 \%$ cases. Postoperative ventilator and inotropes support required in $59 \%$ and $55 \%$ cases respectively. Hospital stay was prolonged $>7$ days in $75 \%$ cases.

Table 4: Risk factors associated with $\mathrm{OH}$.

\begin{tabular}{|lll|}
\hline Risk factor & Frequency & $\%$ \\
\hline Previous Lscs & 23 & 48 \\
\hline Placental causes & 26 & 55.3 \\
\hline Abruption & 12 & 25.5 \\
\hline Placenta previa & 9 & 19.1 \\
\hline Pacenta acreta & 5 & 10.6 \\
\hline Hypertensive disorder & 15 & 31.9 \\
\hline Obstructed labour & 5 & 10.6 \\
\hline Twin pregnancy & 4 & 8.5 \\
\hline H/O instrumentation & 2 & 4.2 \\
\hline Instumental delivery & 1 & 2.1 \\
\hline
\end{tabular}

Table 5: Clinical parameters of women.

\begin{tabular}{|c|c|c|}
\hline Clinical parameters & Frequency (N) & $\%$ \\
\hline \multicolumn{3}{|c|}{ Preoperative Hb (gm\%) } \\
\hline$<7$ & 22 & 46 \\
\hline$>7$ & 25 & 53 \\
\hline \multicolumn{3}{|c|}{ Clinical status on admission } \\
\hline In shock & 13 & 27.6 \\
\hline Not in shock & 34 & 72 \\
\hline \multicolumn{3}{|l|}{ BT requirement } \\
\hline Yes & 47 & 100 \\
\hline$<4$ units & 17 & 36 \\
\hline$>4$ units & 25 & 53 \\
\hline No & 0 & 0 \\
\hline \multicolumn{3}{|l|}{ ICU admission } \\
\hline Yes & 44 & 93 \\
\hline No & 3 & 6.3 \\
\hline \multicolumn{3}{|c|}{ Ventilator requirement } \\
\hline Yes & 28 & 59 \\
\hline No & 19 & 40 \\
\hline \multicolumn{3}{|c|}{ Inotropes requirement } \\
\hline Yes & 26 & 55 \\
\hline No & 21 & 44 \\
\hline \multicolumn{3}{|l|}{ Hospital stay $(\mathrm{N}=36)^{*}$} \\
\hline Upto 7 days & 9 & 25 \\
\hline$>7$ days & 27 & 75 \\
\hline \multicolumn{3}{|l|}{ Maternal outcome } \\
\hline Life saved & 36 & 76.5 \\
\hline Mortality & 11 & 23.4 \\
\hline
\end{tabular}

*exclude cases of maternal death
Table 6 shows distribution of maternal complications among $\mathrm{OH}$ cases. Only 2 cases $(4.2 \%)$ of bladder injury recorded. Intraoperative hypovolumic shock was noted in $21 \%$ cases due to hemorrhage during surgery. Postoperative complications recorded as DIC (29\%), renal failure (12\%), wound gape (17\%) and septic shock $(14.8 \%)$. Postoperative pelvic collection and relaprotomy is not recorded in any case.

Table 7 shows clinical analysis of maternal death in $\mathrm{OH}$ cases. It is found that out of 11 cases of maternal death, $45 \%$ were primipara and $54 \%$ were multipara. Gestational agewise distribution shows 1 case (9\%) and 2 cases $(18 \%)$ of $1^{\text {st }}$ and $2^{\text {nd }}$ trimester respectively, Most cases $(72 \%)$ were of $3^{\text {rd }}$ trimester. Most $(45 \%)$ cases of postpartum $\mathrm{OH}$ and $27 \%$ cases of cesarean and postabortal $\mathrm{OH}$, each. Most common indication was atonic $\mathrm{PPH}(45 \%)$ followed by traumatic $\mathrm{PPH}$ in $36 \%$ cases (which includes postinstumentation cases of $1^{\text {st }}$ trimester and one case of $2^{\text {nd }}$ trimester and 2 case of $3^{\text {rd }}$ trimester with forcep delivery and rupture uterus VBAC), placenta acreta (includes a case $2^{\text {nd }}$ trimester) and sepsis (includes case of FTND) each. Admission to death interval was $<24$ hours in $7(63 \%)$ cases, (out of which 5 cases where in shock status clinically on arrival) and $>24$ hours in $36 \%$ cases. Cause of death found to be DIC in all cases as an end stage of haemorrhagic shock. DIC was complicated with renal failure in $54 \%$ cases and with septic shock in $45 \%$ cases.

Table 8 shows fetal outcome shows $84 \%$ live birth and $15 \%$ stillbirth. There were $20 \%$ NICU admission for respiratory distress and prematurity. Neonatal death was recorded in 3 cases $(6 \%)$.

Table 6: Maternal complication.

\begin{tabular}{|lll|}
\hline Complication & $\begin{array}{l}\text { Frequency } \\
(\mathbf{N})\end{array}$ & $\%$ \\
\hline Intraoperative & & \\
\hline Bladder injury & 2 & 4.2 \\
\hline $\begin{array}{l}\text { Intraoperative hypovolumic } \\
\text { shock* }\end{array}$ & 10 & 21.2 \\
\hline Postoperative & & \\
\hline DIC & 14 & 29.7 \\
\hline Renal faliure & 6 & 12.7 \\
\hline Wound gape & 8 & 17 \\
\hline Septic shock & 7 & 14.8 \\
\hline $\begin{array}{l}\text { Post operative pelvic } \\
\text { collection }\end{array}$ & 0 & 0 \\
\hline Relaprotomy & 0 & 0 \\
\hline Mortality & 11 & 23.4 \\
\hline
\end{tabular}

*those patients who were clinically stable on admission, but landed in hypovolumic shock intraoperatively due to haemorrhage 
Table 7: Clinical analysis of maternal death in $\mathrm{OH}$ cases $(\mathrm{n}=11)$.

\begin{tabular}{|c|c|c|}
\hline Characteristics & Frequency (N) & $\%$ \\
\hline \multicolumn{3}{|l|}{ Parity } \\
\hline Primipara & 5 & 45.4 \\
\hline Multipara & 6 & 54.5 \\
\hline \multicolumn{3}{|l|}{ Gestational age } \\
\hline $1^{\text {st }}$ trimester & 1 & 9 \\
\hline $2^{\text {nd }}$ trimester & 2 & 18.1 \\
\hline $3^{\text {rd }}$ trimester & 8 & 72 \\
\hline \multicolumn{3}{|l|}{ Previous scar } \\
\hline Present & 4 & 36.3 \\
\hline Absent & 7 & 63.6 \\
\hline \multicolumn{3}{|l|}{ Type of $\mathrm{OH}$} \\
\hline Postpartum & 5 & 45.4 \\
\hline After vaginal delivery & 3 & 27 \\
\hline Post cesarean & 2 & 18.1 \\
\hline Cesarean & 3 & 27 \\
\hline Postabortal & 3 & 27 \\
\hline \multicolumn{3}{|l|}{ Indication of $\mathrm{OH}$} \\
\hline Atonic PPH & 5 & 45.4 \\
\hline Trumatic PPH (include rupture uterus) & 4 & 36.3 \\
\hline Placenta acreta & 1 & 9 \\
\hline Sepsis & 1 & 9 \\
\hline Other & 0 & 0 \\
\hline \multicolumn{3}{|l|}{ Risk factors } \\
\hline preeclampsia & 3 & 27 \\
\hline Abruption & 3 & 27 \\
\hline Twins & 3 & 27 \\
\hline Placenta previa & 1 & 9 \\
\hline $\mathrm{h} / \mathrm{o}$ instrumentation & 2 & 18.1 \\
\hline Instrumental delivery & 1 & 9 \\
\hline On admission in shock status & 5 & 45.4 \\
\hline \multicolumn{3}{|l|}{ Admission to death Interval } \\
\hline$<24$ hours & 7 & 63.6 \\
\hline$>24$ hours & 4 & 36.3 \\
\hline \multicolumn{3}{|l|}{ Cause of death } \\
\hline DIC with renal failure & 6 & 54.5 \\
\hline DIC with septic shock & 5 & 45.4 \\
\hline
\end{tabular}

Table 8: Fetal outcome ( $\mathrm{n}=45$ including 4 twin cases).

\begin{tabular}{|lll|}
\hline Outcome & Frequency(n) & $\%$ \\
\hline IUD & 7 & 15.5 \\
\hline Live & 38 & 84.4 \\
\hline NICU admission & 9 & 20 \\
\hline Neonatal death & 3 & 6.6 \\
\hline
\end{tabular}

\section{DISCUSSION}

As shown in Table 9, rate of $\mathrm{OH}$ in our study is similar to other studies, done indifferent parts of India. The incidence in previous studies ranged from 0.2 per 1000 births in the developed countries to 5.6 per 1000 births in the low and middle-income countries. ${ }^{10}$ Most common age group in our study is 21-30 years which is similar with other studies. Younger age of our patients is possibly because our hospital caters to low socioeconomic urban and rural population where education level is lower and age at marriage among women is lower our study, we found that most of the patients were booked, similar to other studies which indicate booking status does not much alter the rate of $\mathrm{OH}$, because even though patients getting ANC care throughout, but unexpected complications arising during labour like PPH may need $\mathrm{OH}$. So important recommendation are delivery by skilled birth attenadant, active management of third stage of labour, delivery of patients with risk factors at tertiary health care facility with 24 hours availability of specialist and blood bank facilities. 
Most common indication in our study was atonic PPH $55 \%$ similar to other studies (as studies from developing countries like India) except Agarwal S et al. But there has been a recently changing trend worldwide especially in developed countries, where morbidly adherent placenta has taken over uterine atony as the major cause for EPH., attributed to better management of postpartum hemorrhage with uterotonic agents and also due to increase in cesarean deliveries. But this change is yet to reflect in our population as uterine atony still continues to be leading cause for EPH in our study followed by uterine rupture and placenta accreta. Most of the patients in our study were referred patients $(68 \%)$ where vaginal delivery had been tried and some were referred after a possible diagnosis of rupture uterus. There has been ample attempt in training birth attendants in early detection of high risk cases, effective use of partogram and effective management of postpartum hemorrhage with uterotonic agents. But the present study shows that there is need for early referral, and improving access to better obstetric care.

Majority parity is multipara seen in all studies which is one of the important risk factor for $\mathrm{OH}$ along with previous lscs. This in turn, is risk factor placental causes like placenta previa, placenta accreta and abruption. Also hypertensive disorder as risk factor was found in $31 \%$ cases which increases chances of abruption, uterine atony and coagulopathy, in turn increases risk of PPH.

In our study, we also specifically noted 6 cases of postabortal $\mathrm{OH}$. Out of which $4(66 \%)$ were previous lscs. The indication was uterine rupture in 4 cases, (instrumentation in 2 cases) and, atonic PPH in 1 cases and placenta acreta in 1 case. This indicates that $\mathrm{OH}$ is, also requires in early pregnancy for scar rupture and placental complication due to increased incidence of previous lscs.

Intraoperative bladder injury incidence was less in our studies compared to other studies as in most of our cases subtotal $\mathrm{OH}$ was done rather than total which minimizes chances of bladder injury and reduces surgery timing, which is beneficial, anesthesia point of view.

In our study, most common mode of delivery was cesarean $65 \%$, similar to other studies. ${ }^{7-10}$ This because half of the cases were previous LSCS cases, which bounds to repeat cesarean delivery $(89 \%$, in our study) as mode of delivery. Also primary cesarean section rate is rising worldwide (in our study 63\%). This suggestive of cesarean delivery itself may increases the risk of $\mathrm{OH}$. So, policies need to be made to decrease primary cesarean section rate at institutional and local levels.

Table 9: Comparison of results with other studies.

\begin{tabular}{|c|c|c|c|c|c|}
\hline Characteristics & $\begin{array}{l}\text { Our study, } 2020 \\
\text { (VDGIMS, Latur) }\end{array}$ & $\begin{array}{l}\text { Bhat et } \\
\text { al, } 2016^{7}\end{array}$ & $\begin{array}{l}\text { Deepak AV } \\
\text { et al, } 2017^{8}\end{array}$ & 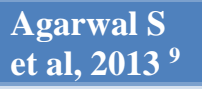 & Hublidar et al, $2016^{10}$ \\
\hline Incidence/rate & $\begin{array}{l}0.11 \% \\
(1.1 \text { per } 1000)\end{array}$ & $0.38 \%$ & $0.29 \%$ & 0.4 per 1000 & 0.7 per 1000 \\
\hline $\begin{array}{l}\text { Most common } \\
\text { age group (years) }\end{array}$ & $21-30(68 \%)$ & $\begin{array}{l}26-30 \\
(46 \%)\end{array}$ & $\begin{array}{l}20-35 \\
(87 \%)\end{array}$ & $26-30(44 \%)$ & $27.6+-3.7$ \\
\hline Major Parity & Multipara (68\%) & $\begin{array}{l}\text { Multipara } \\
73 \%\end{array}$ & $\begin{array}{l}\text { Multipara } \\
88 \%\end{array}$ & $\begin{array}{l}\text { Multipara } \\
83 \%\end{array}$ & Multipara $90 \%$ \\
\hline Booking stats & Booked $76 \%$ & $\begin{array}{l}\text { Unbooked } \\
60 \%\end{array}$ & Booked & $\begin{array}{l}\text { Booked } \\
50 \%\end{array}$ & \\
\hline $\begin{array}{l}\text { Most common } \\
\text { indication }\end{array}$ & $\begin{array}{l}\text { Atonic PPH } 55 \% \text {, } \\
\text { Rupture } 23 \% \text {, } \\
\text { acreta } 10 \%\end{array}$ & PPH 40\%, & $\begin{array}{l}\text { Atonic } \\
\text { PPH50\% }\end{array}$ & $\begin{array}{l}\text { Placent } \\
\text { acreta } 38 \% \text {, } \\
\text { PPH } 36 \%\end{array}$ & $\begin{array}{l}\text { Atonic PPH } 38 \% \text {, rupture } \\
23 \% \text {, acreta } 19 \%\end{array}$ \\
\hline $\begin{array}{l}\text { Most common } \\
\text { risk factor }\end{array}$ & $\begin{array}{l}\text { Previous lscs } \\
48 \% \text {,placental } \\
\text { causes }(55 \%), \text { hypertensive } \\
\text { disorder } 31 \%\end{array}$ & $\begin{array}{l}\text { Previous } \\
\operatorname{lscs} 40 \%\end{array}$ & $\begin{array}{l}\text { Previous lscs } \\
60 \% \text {,placental } \\
\text { causes } 37 \%\end{array}$ & $\begin{array}{l}\text { Previous } \\
\operatorname{lscs} 44 \%\end{array}$ & Previous lscs $47 \%$ \\
\hline $\begin{array}{l}\text { Most common } \\
\text { complication }\end{array}$ & $\begin{array}{l}\text { DIC } 29 \% \text {, renal failure } \\
12 \% \text {, bladder injury } 4.2 \%\end{array}$ & $\begin{array}{l}\text { Febrile } \\
\text { morbidity } \\
26 \%, \\
\text { septic } \\
\text { shock } \\
13 \%\end{array}$ & $\begin{array}{l}\text { Febrile } \\
\text { morbidity } \\
32 \%, \text { DIC } \\
12.5 \%, \\
\text { bladder injury } \\
15 \%\end{array}$ & $\begin{array}{l}\text { Febrile } \\
\text { morbidity } \\
19 \%, \text { bladder } \\
\text { injury } 11 \% \text {, } \\
\text { DIC } 11 \%\end{array}$ & $\begin{array}{l}\text { Renal failure } 4.8 \% \text {, } \\
\text { septicemia } 9.5 \% \text {, bladder } \\
\text { injury } 14.2 \%\end{array}$ \\
\hline $\begin{array}{l}\text { Maternal death } \\
\text { rate }\end{array}$ & $23 \%$ & $6.7 \%$ & $5 \%$ & $19.4 \%$ & $4.8 \%$ \\
\hline Type of OH & Subtotal $95 \%$ & $\begin{array}{l}\text { Total } \\
66 \%\end{array}$ & Total $60 \%$ & $\begin{array}{l}\text { Subtotal } \\
50 \%\end{array}$ & Subtotal $61 \%$ \\
\hline $\begin{array}{l}\text { Major Mode of } \\
\text { delivery }\end{array}$ & Cesarean $65 \%$ & cesarean & $\begin{array}{l}\text { Cesarean } \\
85 \%\end{array}$ & $\begin{array}{l}\text { Cesarean } \\
50 \%\end{array}$ & Cesarean $66 \%$ \\
\hline
\end{tabular}


$\mathrm{OH}$ is lifesaving operation $(76 \%$ mothers were saved in our study), but at the same time it is associated with high rate of postoperative morbidity, complications and mortality. It is also reflected in our study in form of $100 \%$ blood transfusion required (in 53\% massive transfusion), ICU requirement in $93 \%$ cases, ventilator and inotropes support requirement in more than half of the patients. Prolonged hospital stay $>7$ days needed in $75 \%$ patients. This is because many patients are in hypovolumic shock on admission and also go in shock intraoperatively due to massive blood loss. High mortality rate of $23 \%$ is noted in our study as $\mathrm{OH}$ is associated with high rate complication (in our study DIC 29\%, Septic shock 14\%, renal failure $12 \%$.) which is also associated with $27 \%$ came with shock status clinically on admission. To prevent complications and in turn, mortality, needs on time decision of $\mathrm{OH}$, experienced surgeon, and liberal blood transfusion are very important which check on landing patient in DIC, end stage of shock, further complications are avoided.

\section{CONCLUSION}

Measures to reduce incidence of $\mathrm{OH}$ and prevent this catastrophic event are proper antenatal care with assessment of risk factors for $\mathrm{OH}$ and early referral, worldwide attempt should be done to reduce cesarean section rate, more efforts for implementation of family planning and welfare in developing country to prevent obstetric haemorrhage. Moreover, timely decision, liberal blood transfusion and speedy surgery by an experienced surgeon are important in the management of this life saving procedure to avoid complications. Post graduate training should include the learning of this procedure and at the same time policies to reduce its incidence.

Funding: No funding sources

Conflict of interest: None declared

Ethical approval: Not required

\section{REFERENCES}

1. Cunningham FG. Cesarean delivery and peripartum hysterectomy. $24^{\text {th }}$ ed. Williams Obstetrics. 2005:587-606.

2. Morice P, Narducci F, Mathevet P, Marret H, Darai E, Querleu D. French recommendations on the management of invasive cervical cancer during pregnancy. Inter $\mathrm{J}$ Gynecol Cancer. 2009;19(9):1638-41.

3. Karayalcin K, Ozcan S, Ozyer S, Mollama L, Danishman N. Emergency peripartum Hysterectomy Arch Gynecol Obstet. 2010;283(4):723-7.

4. Christopoulos P, Hassiakos D, Tsitoura A, Panoulis K, Papadias K, Vitoratos N. Obstetric hysterectomy: a review of cases over 16 years. J Obst Gynaecol. 2011 Feb 1;31(2):139-41.

5. Chawla J, Arora CD, Paul M, Ajmani SN. Emergency obstetric hysterectomy: A retrospective study from a teaching hospital in North India over eight years. Oman med J. 2015;30(3):181.

6. Cameron CA, Roberts CL, Olive EC, Ford JB, Fischer WE. Trends in postpartum haemorrhage. Austra N Zea J Pub Heal. 2006;30(2):151-6.

7. Bhat S, Bhave S. Obstetric Hysterectomy a life saving procedure and its complication. Int $\mathrm{J}$ Med and Dent Sci. 2016;5(1):996-1001.

8. Deepak AV, Jacob KJ, Maria SP. Peripartum hysterectomy. Int $\mathrm{J}$ Reprod Contracept Obstetet Gynecol, 2017;6(8):3590-3.

9. Agrawal S, Yadav R, Raghunandan C, Dhingra S, Kaur H. Peripartum hysterectomy in a teaching hospital in India. Asian J Med Sci. 2013;4(1):5-9.

10. Hoblidar S, Sunil Kumar KS, Desai RM. Emergency peripartum hysterectomy: a retrospective study of 7 years. Int J Reprod Contracept Obstetet Gynecol. 2016;5(9):3112-5.

Cite this article as: Pawar AG, Shinde MA, Sarasjothi M, Nemagouda PB. Five-years review of obstetric hysterectomy at tertiary care center. Int J Reprod Contracept Obstet Gynecol 2021;10:308-14. 